\title{
PAWEL TRZOS'
}

Uniwersytet Kazimierza Wielkiego w Bydgoszczy

Wydział Pedagogiki i Psychologii

Instytut Pedagogiki

\section{(Dwu)podmiotowość relacji wychowania wobec codzienności edukacji dziecka}

The Dual-subjectivity of Upbringing Relation Towards Everyday Child Education

\section{WPROWADZENIE}

Procesy edukacji w naturalnym środowisku wychowawczym, jakim jest rodzina, wyznaczone są z pewnością dyspozycjami rozwojowymi (w tym społecznymi, intelektualnymi, poznawczymi, emocjonalnymi) dziecka i wielorakimi kompetencjami rodziców. Kształtuje to warunki optymalizacji wielu procesów edukacji dziecka, a wychowanie okazuje się jednym z kluczowych procesów kształtowania jego integralnej osobowości. Ważne jest, aby w złożonej przestrzeni edukacji w rodzinie respektowane były prawa i potrzeby partnerów wychowania, tj. dorosłego (rodzica) i dziecka. Dotyczy to wspólnego doświadczania codziennych zdarzeń, relacyjności wspólnego przeżywania interakcji wychowawczych, skłonności do poszukiwania nowych rozwiązań w komunikacji, wspólnego podzielania

\footnotetext{
${ }^{1}$ Paweł Adam Trzos, doktor nauk humanistycznych w zakresie pedagogiki. Absolwent dwóch kierunków studiów: wychowania muzycznego oraz pedagogiki. Adiunkt w Instytucie Pedagogiki na Wydziale Pedagogiki i Psychologii Uniwersytetu Kazimierza Wielkiego w Bydgoszczy. Od 1999 roku zawodowo związany także z Instytutem Pedagogiki w Państwowej Wyższej Szkole Zawodowej w Koninie, gdzie pracuje na stanowisku dydaktycznym docenta. Naukowo związany ze środowiskiem pedagogiki wczesnoszkolnej oraz pedagogiki muzyki, w których to obszarach ogniskuje się jego główna uwaga. Jest autorem kilkudziesięciu artykułów naukowych i dwóch monografii, które dotyczą problemów wczesnej edukacji oraz społeczno-kulturowych aspektów wspierania kreatywnego i innowacyjnego rozwoju dziecka. Jest członkiem Polskiego Towarzystwa Pedagogicznego oraz Bydgoskiego Towarzystwa Naukowego.
} 
wzajemnej uwagi oraz aktywizacji metod wychowawczych. Świadczyć to wszystko może o praktycznym uzasadnieniu refleksji nad jakością dwupodmiotowego charakteru wychowania w rodzinie.

Artykuł dotyczy analizy problematyki podmiotowości we wczesnej edukacji dziecka. Zagadnienia te, ujęte w perspektywie pedagogicznej, są w opracowaniu tym zogniskowane na procesie wychowania. Przyjęty kontekst osobowych relacji pomiędzy naturalnymi podmiotami eksponuje potrzebę interdyscyplinarnej (w tym socjologicznej, pedagogicznej, antropologicznej, religijnej) refleksji nad rolą „wspólnoty” i „doświadczania siebie” w społecznej praktyce edukacji. Takimi „doświadczającymi siebie” kompetentnymi podmiotami są dziecko i jego rodzice, którzy często odgrywają rolę pierwszego nauczyciela. Dlatego mówiąc o rodzicu i pedagogicznym uzasadnieniu jego wychowawczych oddziaływań, coraz częściej widzimy w nim także „kompetentnego nauczyciela”, tłumacza codziennych zdarzeń i współuczestnika wzajemnych interakcji, które oba te podmioty generują i jakim sami na co dzień są poddawani. Wiedza rodziców o warunkach rozwijania integralnej osobowości dziecka jest wytwarzana niejako „na co dzień", właśnie poprzez interpretację wzajemnych doświadczeń związanych z podzielaniem wspólnej uwagi ogniskowanej na roli osób, wzorów i potrzebach wzrastania dziecka w rodzimej rzeczywistości.

\section{(DWU)PODMIOTOWOŚĆ W PROCESIE EDUKACJI DZIECKA}

Codzienne poznawanie i doświadczanie roli partnera w edukacji dziecka, związanej z realizacją jego rozwojowych potrzeb oraz analizą osobistych doświadczeń tworzących zręby codziennej wiedzy rodziców o wychowaniu w rodzinie, często staje się kontekstem opisu przestrzeni edukacji ujmowanej w kategoriach rozumności i humanistycznej wrażliwości.

Jak zauważyła Ewa Filipiak, w procesie kreowania siebie istotne jest respektowanie potrzeb obojga partnerów: dorosłego i dziecka². Właściwe rozpoznawanie obszarów własnej działalności prowadzi do kształtowania sylwetki poszukujących / / ewaluujących podmiotów. W przypadku opisu subiektywnego doświadczania zdarzeń wychowawczych w rodzinie i kontaktu osobowego dziecka z dorosłym realizacja procesu wychowania szczególnie eksponuje potrzebę upodmiotowienia wzajemnych interakcji.

Dążenie do optymalizacji integralnego rozwoju dziecka w świecie dorosłych rodziców (w tym minimalizowanie możliwości wystąpienia zjawisk ewentualnego ,analfabetyzmu funkcjonalno-kulturowego"3) wiąże się z potrzebami dwupod-

\footnotetext{
${ }^{2}$ Por. E. Filipiak, Wspólna aktywność dziecka i nauczyciela w strefie rozwoju, w: Rozwijajacy się człowiek w zmieniajacym się świecie, red. J. Trempała, Bydgoszcz 1995, s. 226.

${ }^{3}$ Konsekwencją braku (niedoboru) realizacji procesu wychowania staje się forma analfabetyzmu kulturowego.
} 
miotowej kreacji świata. Na czym ta dwupodmiotowość może polegać? Sugestii dostarcza Bernsteinowskie rozumienie pedagogii, ogniskujące uwagę na wspólnej roli dorosłych „dawców” (dostarczycieli, przekazicieli, ewaluatorów) wiedzy, norm i wzorów postępowania oraz „biorców” (dzieci) przyswajających to, co niosą ze sobą powtarzane przez dawców na co dzień działania ${ }^{4}$. Można sądzić, że przy właściwym rozpoznaniu i regulowaniu wewnętrznej motywacji obojga partnerów powinny się optymalizować kluczowe relacje osobowe, w których:

- dziecko/biorca: to aktywny i mniej doświadczony partner; wie „inaczej”, ma prawo do osiagania własnego sukcesu, choć mówi/sugeruje „potrafię z Twoją pomocą"; jest samodzielnym i świadomym swoich umiejętności podmiotem;

- dorosły/rodzic/dawca: to kompetentny mediator, interpretator dziecięcych doświadczeń i pośrednik pomiędzy dzieckiem a transmitowaną i wytwarzaną wiedzą (i jej wzorami) oraz jej codzienną rzeczywistością; dyskretny opiekun i obserwator 5 .

Relacje te przenikają się wzajemnie, tworząc dwukierunkowy kontekst podejmowanych działań.

Dwupodmiotowość dorosłego i dziecka realizuje się w konkretnych sytuacjach zadaniowych, których znaczenie dodatkowo naświetlane jest dynamiką wzajemnych interakcji (rys. 1).

Przyjęto, że podmiotowość rozpatruje się w aspektach wewnętrznej organizacji człowieka $\mathrm{z}$ otoczeniem, jego zdolności rozpoznawania sytuacji, w której się znajduje, oraz zdolności interpretacji napływających z otoczenia bodźców. Wszystko to odbywa się w kontekście stawianych wzajemnie zadań. Podmiotowość dorosłego/rodzica i dziecka determinowana jest więc czynnikami wewnętrznymi, społecznymi i płynącymi ze świata empirii (w tym obserwacji) doświadczeniami. Dorosły/rodzic oraz dziecko jako partnerzy i współpodmioty konkretnych zdarzeń interakcyjnych poddają się oddziaływaniu własnych emocji, kształtując w ten sposób płaszczyznę wzajemnego postrzegania. Można bowiem sądzić, że dziecko, które jest traktowane jako aktywny i kompetentny podmiot oddziaływań dorosłego, także uczestniczy w organizacji przestrzeni wspólnego rozwoju nie tylko aktywnie, ale przede wszystkim świadomie, z wysoką motywacją samopoznania i twórczej samorealizacji. Ważne okazują się wspólne przeżycia emocjonalne i kształtująca się świadomość jako dynamiczna płaszczyzna wytwarzania wiedzy osobistej popartej doświadczeniami codziennego przeżywania świata. Kontekst ten eliminuje czynniki nad wyraz niekorzystne, gdy dziecko czuje lęk przed ignorancją, brakiem zainteresowania jego światem przeżyć, dezaprobatą dorosłego lub brakiem szacunku do swoich racji i potrzeb.

\footnotetext{
${ }^{4}$ Por. T. Hejnicka-Bezwińska, Pedagogika ogólna. Seria: Pedagogika wobec współczesności, Warszawa 2008, s. 40.

${ }^{5}$ E. Filipiak, Wspólna aktywność dziecka i nauczyciela w strefie rozwoju, dz. cyt., s. 223.
} 


\begin{tabular}{ll}
\multicolumn{1}{c}{ Dziecko } \\
\cline { 2 - 2 } - ćwiczy nowe umiejętności,
\end{tabular}

Źródło: na podstawie analizy literatury ${ }^{6}$.

Rys. 1. Dziecko i dorosły jako partnerzy dwupodmiotowych relacji

Wrażliwość pedagogiczna rodziców kierunkuje badanie dynamiki spełniania potrzeb dziecka jak choćby: ruchu, aktywności umysłowej, dyscypliny, radości, poznawczych, społecznych, osobowościowych, samoakceptacji i autoedukacji. Niezawodność w realizacji tych potrzeb sprawia, że dziecko, mimo osadzenia w często ubogim materialnie i kulturowo w środowisku rodzinnym, ma szansę rozwijać się integralnie.

Tak rozumiane znaczenie samorealizacji dziecka w codziennej edukacji znajduje uzasadnienie w procesach wszechstronnej aktywizacji ucznia. We wczesnej edukacji wszechstronność taka oznaczać może dodatkowo systematyczne projektowanie sytuacji i warunków stymulujących działania twórcze i postawy ekspresyjne. Podmiotowość odniesie się oczywiście do respektowania, rozwijania i wykorzystywania ogólnych uzdolnień, zainteresowań i pozostałych kompetencji także w tym zakresie.

Przekonanie Abrahama H. Maslowa istotnie inspiruje tezami, że dzieci, które w pierwszych latach rozwoju będą miały zaspokojone potrzeby samourzeczywistnienia, w życiu dorosłym cechować się będą:

\footnotetext{
${ }^{6}$ Tamże, s. 222-227.
} 
- bardziej adekwatnym spostrzeganiem rzeczywistości i lepszym kontaktem $\mathrm{z}$ nią niż przeciętne jednostki,

- wysokim stopniem akceptacji siebie, innych ludzi i ułomności natury ludzkiej,

- spontanicznością w myśleniu i życiu emocjonalnym,

- wysokim stopniem autonomii m.in. wiernością swoim przekonaniom, umiejętnością rozwijania swoich planów i zainteresowań,

- silnie rozwiniętym zmysłem etycznym,

- zdolnościami twórczymi i inwencją w wielu dziedzinach życia,

- stałą świeżością w ocenie zjawisk?

W realizacji takich warunków wczesnego rozwoju dziecka potrzebna jest współpraca pomiędzy rodzicami i nauczycielami jako kompetentnymi przedstawicielami dwóch podstawowych środowisk wychowawczych, tj. rodziny i szkoły. W konstruowaniu przestrzeni wzajemnych działań dorosłych (rodziców, nauczycieli) i dzieci proponuje się coraz częściej podejście humanistyczne w wariancie interpretacyjnym, gdzie ważne znaczenie przypisuje się dwustronnej komunikacji pomiędzy podmiotami i ich uprawnieniami do samostanowienia własnych kompetencji w ramach reprezentowanych środowisk wychowawczych. Sugestii w tym zakresie dostarczają intencje projektu przygotowanego przez Zespół Przygotowania Pedagogicznego Rady ds. Kształcenia Nauczycieli przy MEN z 14 maja 1998 roku. Przewidywano w nim potrzebę rozwijania szerokich kompetencji pedagogów, a uwagę skoncentrowano na kompetencjach komunikacyjnych, informatyczno-medialnych, prakseologicznych, jak również kompetencjach kreatywnych, które wyrażają się innowacyjnością i niestandardowością działań. Projekt określał takiego pedagoga, który

potrafi działać na rzecz zwiększenia autonomii podmiotów edukacyjnych; umie myśleć krytycznie, potrafi stymulować rozwój krytycznego i samodzielnego myślenia u swoich wychowanków oraz zainspirować ich samokształcenie i pracę nad sobą. Umie ponadto zaplanować własną koncepcję doskonalenia i samokształcenia, umie badać własną praktykę, dokonać nad nią refleksji i tworzyć wiedzę na podstawie własnych doświadczeń zawodowych ${ }^{8}$.

Chodzi o to, aby rodzic i nauczyciel odczuwali autonomię w wyborze strategii i procedur wychowania. Wszystkie właściwości codziennej pracy z dzieckiem, które sprzyjają uzyskiwaniu lepszych efektów, powinny zmierzać do nowatorstwa

${ }^{7}$ A.H. Maslow, Toward a Psychology of Beign, New York 1968, za: I. Strachanowska, Wybrane zagadnienia uczestnictwa uczniów klas I-III w zajęciach pozalekcyjnych, w: Nauczyciel w toku pracy, red. P. Prusak, Zeszyty Naukowe Wyższej Szkoły Pedagogicznej. Studia Pedagogiczne, Bydgoszcz 1993, z. 26, s. 178-179.

${ }^{8}$ Z. Konaszkiewicz, Nauczyciel muzyki między rutyna a twórczościq, „Kwartalnik Polskiej Sekcji ISME” nr 4, 1999, s. 57. 
pedagogicznego, a ich konstytutywną cechą jest właśnie podmiotowość nauczyciela ${ }^{9}$. Kluczowa jest rola kompetencji takiego wychowawcy, wśród których wyróżniają się kompetencje etyczno-moralne i dialogowe (rys. 2).

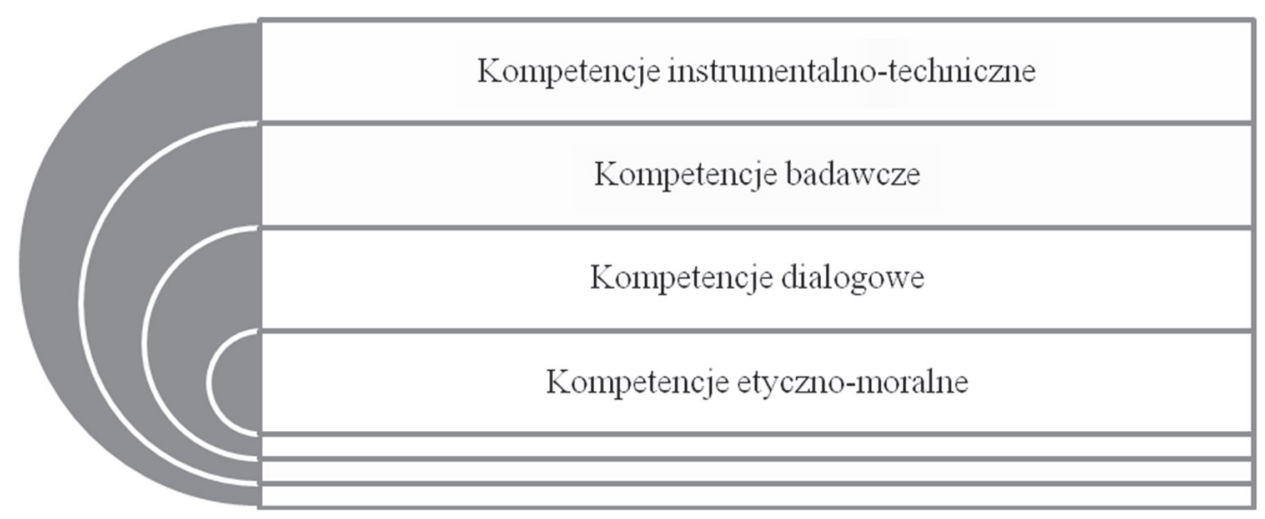

Rys. 2. Praktyka pedagogiczna kompetentnego wychowawcy

Kompetencje dorosłych, obok wielu innych (w tym teleologicznych, proceduralnych, diagnostycznych, konstruktywistycznych, komunikacyjnych i wreszcie twórczych), powinny uwzględniać także umiejętność badawczego opisu zjawisk związanych z działaniami we wspólnym doświadczaniu codziennych relacji wychowawczych ${ }^{10}$. Chodzi o umiejętność obserwacji zjawisk, stosowania praktycznych kategorii ich opisu i wyprowadzania kluczowych dla praktyki wychowawczej wniosków.

\section{CODZIENNOŚĆ I WIEDZA CODZIENNA O WYCHOWANIU}

Naturalne doświadczanie codziennej rzeczywistości staje się źródłem wiedzy o przestrzeni, w jakiej przyszło nam działać. Rola potocznych argumentacji płynących ze świata codziennego doświadczania fenomenu życia często wiąże się z tym, co okazuje się zmysłowo i intuicyjnie doświadczanym przednaukowym „byciem w świecie” ${ }^{\prime 1}$. Stąd refleksja o integralnej edukacji dziecka i celowościo-

${ }^{9}$ S. Kawula, Elementy nowego paradygmatu w pracy szkoty i nauczyciela, w: Problemy etyczno-deontologiczne zawodu nauczycielskiego $w$ okresie przemian ustrojowych w Polsce, red. A. Tchorzewski, Bydgoszcz 1993, s. 151.

${ }^{10}$ M. Kołodziejski, Music Teacher as a Researcher of Educational Process, "Musikas Zinatne Sodien: Pastavigais un Mainigais. Zinatniskorakstukrajums" 2012, v. 4, s. 363-364, 366-367.

${ }^{11}$ Por. K. Ablewicz, Teoretyczne i metodologiczne podstawy pedagogiki antropologicznej. Studium sytuacji wychowawczej, Kraków 2003, s. 39. 
wości procesu wychowania (funkcjonalnego, kulturowego) winna być przeniknięta autonomią myślenia pedagogicznego rodziców i nauczycieli jako etyczną powinnością „kompetentnych dorosłych” ${ }^{2}$. Idąc torem myślenia Krystyny Ablewicz, takiej refleksji nie można oderwać od zjawisk wkomponowania procesów edukacji w strukturę życia codziennego człowieka, przy czym samo rozważanie codzienności w praktyce wczesnej edukacji w wielu koncepcjach wychowania (instytucjonalnego, kulturowego, religijnego, potocznego etc.) pozwala przyjrzeć się bliżej sferom współczesnej edukacji i zrealizować zarazem implikacje osobistej i pedagogicznej perspektywy interpretacji rzeczywistości ${ }^{13}$. Wychowanie w codziennych interakcjach dziecko - dorosły uwzględnia nie tylko podmiotowość ich wspólnych dążeń do samorozwoju, realizację potrzeb czy współprzeżywanie własnych ról (rodzinnej, społecznej, religijnej, politycznej czy kulturowej). Sam j ę z y k wiedzy osobistej, którym dorośli i dzieci posługują się w celach obiektywizacji własnych doświadczeń, jest zakorzeniony właśnie w życiu codziennym i - jak zauważyli Peter L. Berger i Thomas Luckmann - nawet wtedy, kiedy jest stosowany do interpretacji doświadczeń w ograniczonych obszarach znaczenia, $\mathrm{w}$ dalszym ciagu odnosi je do wspólnego życia codziennego ${ }^{14}$. Wi e d za d ni a codziennego jest opisywana zatem językiem codziennych doświadczeń i ich znaczeń, a język staje się potocznym i doraźnym rodzajem modyfikowania (czy używając określenia P.L. Bergera, T. Luckmanna „zniekształcania”) ich rzeczywistości przekładanej z powrotem na znaną i podstawową codziennośćc ${ }^{15}$.

Inspirujący w takiej refleksji jest pogląd Mirosławy Marody, który towarzyszy namysłowi o refleksyjności dorosłego w pracy wychowawczej z dzieckiem. Właściwie prowadzenie namysłu nad refleksyjnością rodziców w edukacji dziecka (traktując ich explicite jako refleksyjnych praktyków) sprowadza szereg myśli do problemów tworzenia i funkcjonowania ich wiedzy osobistej o otaczającej ich na co dzień rzeczywistości edukacyjnej. Czyniąc z refleksyjności autonomiczną kategorię opisu działań wychowawczych, nie sposób oderwać się z kolei od innej kategorii myślenia o wychowaniu dziecka, tj. myślenia potocznego. Myślenie potoczne, za pośrednictwem intersubiektywnie komunikowalnego języka, konsekwentnie organizuje i rekonstruuje potoczną wiedzę rodziców, nauczycieli i dzieci o rzeczywistości, jakiej kiedyś i obecnie doświadczają. Towarzyszący pogląd M. Marody wyraźnie eksponuje właśnie ten obszar osobistych konotacji w „codziennym” doświadczaniu rzeczywistości, w tym jej wymiaru edukacyjnego. Powiemy wtedy za autorka, że „wyjaśnianie pewnej kategorii

12 Tamże, s. 12.

${ }^{13}$ Tamże, s. 13.

${ }^{14}$ P.L. Berger, T. Luckmann, Społeczne tworzenie rzeczywistości, thum. J. Niżnik, Warszawa 2010, s. 40-41.

15 Tamże, s. 41. 
działań, a przynajmniej działań refleksyjnych, wymaga uwzględnienia treści posiadanej przez jednostki wiedzy potocznej o rzeczywistości"16.

Takie rozumienie, bliskie zresztą przedstawicielom socjologii fenomenologicznej (eksponowane w stanowiskach choćby Alfreda Schütza, Petera L. Bergera, Thomassa Luckmanna), prezentuje pogląd Jana Szczepańskiego: „[...] wiedza potoczna jest wiedzą o podstawowej warstwie rzeczywistości społecznej, którą nieraz Amerykanie nazywają Monday morning realities of everyday life" 17 . Szczególnie interesujący jest ten socjologiczny trop namysłu nad wiedzą rodziców i nauczycieli o wychowaniu dziecka, którą w skrócie można tutaj za M. Marody określić właśnie jako „wiedzę o rzeczywistości dnia codziennego"18. Co zatem „rzeczywistość dnia codziennego” tworzy? Takie zapytanie może być (a przynajmniej było u J. Szczepańskiego czy A. Schutza) konsekwencją innego pytania o istotę samej wiedzy potocznej.

Rzeczywistość dnia codziennego najlepiej jest określana według kryterium życia ludzi zgoła pomiędzy normalnością a rutyną działań lub inaczej w kategoriach jej oczywistości ${ }^{19}$. Wychowawczą rzeczywistość dnia codziennego w rodzinie można tłumaczyć także, sugerując się myślą P.L. Bergera i T. Luckmanna, jako naturalną i najbardziej osobistą przestrzeń praktyki edukacji dziecka, która przez kluczowe jej podmioty ,jest przyjmowana po prostu i bez zastrzeżeń jako rzeczywistość. Nie wymaga ona dodatkowych weryfikacji i uzasadnień wykraczających ponad lub poza swą obecność" ${ }^{20}$. Tak więc ta oczywista i „,nieodparta sfera faktów” staje się rzeczywistością wychowawczą rodziców i dzieci, która całkowicie odnosi się także do zrutynizowanego obszaru codzienności ich życia i która w gruncie rzeczy wszystkim tym podmiotom ,narzuca się sama”"21.

Stąd uwaga skierowana na znaczenie potocznego myślenia w kształtowaniu codziennej wiedzy pedagogów o wychowaniu okazuje się koniecznym aspektem refleksji o edukacji dziecka w rodzinie. Potoczne myślenie rodziców i ich wiedza o strategiach wychowania zorientowanego na integralność dziecka są niejako „owinięte wokół konkretu” i mają odniesienie właśnie do doświadczeń dnia codziennego, w ich najbardziej bezpośrednim i nieprzetworzonym wydaniu ${ }^{22}$.

${ }^{16}$ M. Marody, Technologie intelektu. Językowe determinanty wiedzy potocznej i ludzkiego dziatania, Warszawa 1987, s. 173.

${ }^{17}$ J. Szczepański, Rozważania o dniu powszednim, „Odra” 3(1980), s. 30.

${ }^{18}$ M. Marody, Technologie intelektu. Językowe determinanty wiedzy potocznej i ludzkiego dziatania, dz. cyt., s. 173.

${ }^{19}$ Taka koncentracja na oczywistości wiedzy potocznej rodzi, zdaniem M. Marody, trudności z wewnętrznym określaniem poziomu oczywistości różnych fragmentów rzeczywistości życia codziennego. Por. M. Marody, Technologie intelektu. Jezzykowe determinanty wiedzy potocznej i ludzkiego działania, dz. cyt., s. 175.

${ }^{20}$ P.L. Berger, T. Luckmann, Społeczne tworzenie rzeczywistości, dz. cyt., s. 37.

${ }^{21}$ Tamże, s. 37-38.

${ }^{22}$ Tamże, s. 177. 
Choć wiedzę tę jakby na własną rękę rodzic musi sobie samodzielnie odtworzyć w konkretnych egzemplifikacjach potocznych pedagogii, to jednak doświadczenia wspólnego z dzieckiem przeżywania zdarzeń wychowawczych (związane ze wspólnymi interesami, emocjami, wartościowaniem, interpretowaniem) stają się podstawowym poziomem myślenia o wyzwaniach procesu wychowania we współczesnym (i złożonym edukacyjnie) świecie (zob. rys. 3$)^{23}$.

\section{inkulturacja}

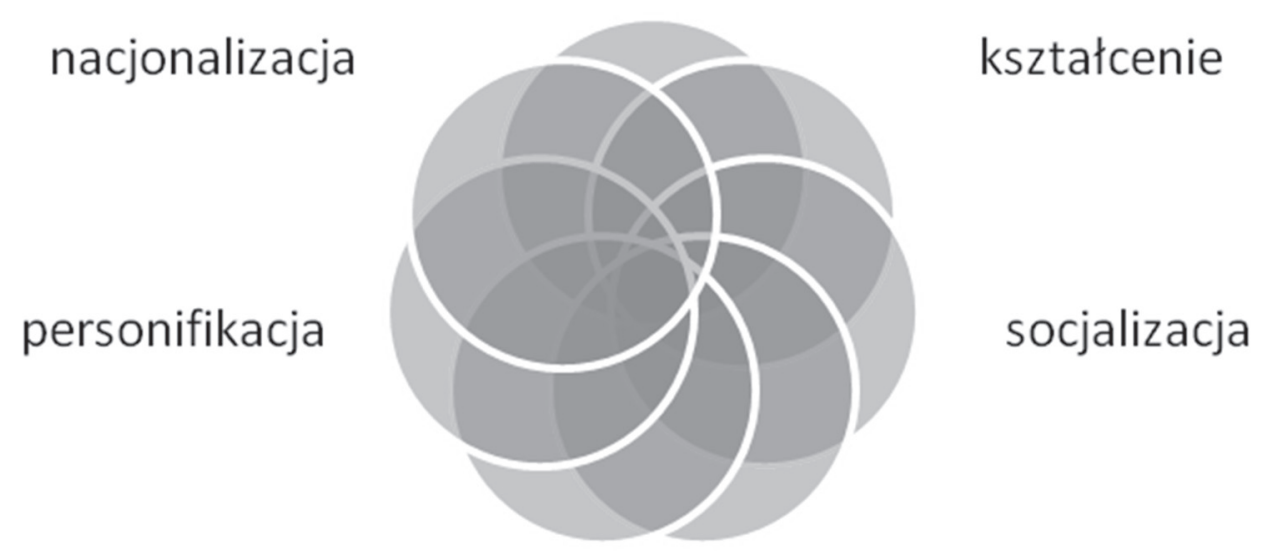

\section{humanizacja wychowanie}

Rys. 3. Wychowanie w polu wybranych procesów edukacji według aktywnego modelu dziesięciościanu edukacyjnego Zbigniewa Kwiecińskiego

Źródło: opracowanie własne na podstawie analizy literatury.

Procesy edukacyjne (zob. rys. 3) realizują koncepcję harmonijnego rozwoju człowieka, refleksyjnego i dojrzałego rodzica, nauczyciela, adaptatora i rekonstruktora konkretnych pedagogii. Choć propozycje Zbigniewa Kwiecińskiego dotyczą wielu innych p ro c e s ó w edukacyjnych, to trudno nie dostrzec wyraźnego znaczenia wychowania w rodzinie wobec działań wynikających z potrzeby realizacji innych procesów, jak choćby: inkulturacja ${ }^{24}$, humanizacja, socjalizacja, personifikacja i kształcenie (rys. 3).

${ }^{23}$ Tamże, s. 177, 235.

${ }^{24}$ Rodzina jako naturalne środowisko edukacji dziecka pierwsza i najsilniej inkulturuje, także w znaczeniu konfrontacji zdobyczy rodzimej kultury otwartej na heterogeniczną wielość we współczesnym i właśnie „heterogenicznym” świecie kultury, edukacji i sztuki. Pisze także o tym Bogusław Śliwerski, zwracając uwagę na aktualność kon- 


\section{RODZINA JAKO NATURALNE ŚRODOWISKO WYCHOWAWCZE}

Obraz własnego dzieciństwa i rodziny jest trwałym elementem w wielu doświadczeniach dorosłych osób. Świadczą o tym doniesienia z badań nad epizodyczną i semantyczną potoczną wiedzą środowisk rodzicielskich. Postawy i orientacje aksjologiczne rodziców często wynikają z doświadczeń wyniesionych $\mathrm{z}$ jakości edukacji rodzinnej. Pomimo różnych, w tym wysoce niepokojących jak zauważył Andrzej Pryba ${ }^{25}$ - tendencji przedmiotowego ujęcia rodziny w refleksji nad „debatującym społeczeństwem” problem podejścia do realizowanych przez nią rozwojowych funkcji jest za każdym razem ujmowany w kontekście społecznym. Kształt publicznej sfery zależy między innymi właśnie od normatywności funkcjonowania rodzin, gdzie kształtują się zdolności życiowe i kompetencje (społeczno-kulturowe, aksjologiczne) rodzących się pokoleń ${ }^{26}$. Rodzina jest pierwszym i najważniejszym podmiotem edukacji dziecka wypełniającym współczesną przestrzeń publiczną, z jej wyzwaniami kulturotwórczymi, aksjologicznymi, religijnymi, tolerancyjnymi i tożsamościowymi. Inną sprawą jest natomiast problem zanurzenia współczesnej rodziny w przestrzeni szans i zagrożeń edukacji dziecka ujawniającej się na kontinuum pomiędzy genetycznym wyposażeniem rodzącej się jednostki z jednej strony a ofertą społeczno-kulturową rodzimego środowiska $\mathrm{z}$ drugiej.

Rodzina jest podstawową grupą społeczną i tworzy zarazem strukturalną jakość w życiu publicznym, stając się jej instytucją. Jej podstawą są charakterystyczne więzi i właściwie funkcjonujący system rodzinny. Rodzina jako instytucja społeczna ma do spełnienia wiele kluczowych funkcji: prokreacyjna, socjalizacyjną,

frontujących się kulturowo wyzwań edukacji w rodzinie, jakie stawia przed nią współczesność. Okazuje się, że „spotkania z inną kulturą nie są już tylko następstwem podróży, ale także oddziaływania mediów. Człowiek potrzebuje w tej sytuacji pomocy w lepszym orientowaniu się w istniejących i konfrontowanych z nim innych kultur". B. Śliwerski, Problemy wychowania w procesie globalizacji, w: Edukacja. Kultura. Teologia. Studia ofiarowane Księdzu Profesorowi Jerzemu Bagrowiczowi z okazji 65. rocznicy urodzin, red. K. Konecki, I. Werbiński, Torun 2003, s. 179. Udział rodziny w procesie inkulturacji dziecka prowadzi do oswojenia z głównymi atrybutami rodzimej kultury oraz - jak można odczytać z nauczania papieża Jana Pawła II - do „zadanego” orientowania na wspólnotę i dialog szczególnych wartości kulturowych (w tym otwieranie się na wartość ich powszechności), w których człowiek staje się właśnie „podmiotem rozwoju”. Zob. P.A. Trzos, Dziecko w rodzinie jako środowisku społecznego „stawania się”, „Teologia i Moralność" 1(15) 2014, s. 119-130.

${ }^{25}$ Wątek ten szerzej rozwinął Andrzej Pryba, zwracając uwagę na deprawujące (w sensie fałszujące) obraz normatywności rodziny wypowiedzi przedstawicieli przestrzeni publicznej jako próbę doraźnego wypełniania kapitału (politycznego, medialnego). Por. A. Pryba, Rodzina podstawowq instytucja $i$ wspólnota życia społecznego?, „Teologia i Moralność” 11(2012), s. 7-8.

${ }^{26}$ Nawiązuję tu do kluczowej definicji „,edukacji” jako ogółu międzygeneracyjnych oddziaływań na osobowość wychowanka czyniących z niego istotę dojrzałą, świadomą, zakorzenioną w danej [rodzimej - dop. mój P.T.] kulturze i zdolną do refleksyjnej afirmacji. Zob. Leksykon PWN. Pedagogika, red. B. Milerski, B. Śliwerski, Warszawa 2000, s. 54. 
emocjonalno-ekspresywną, religijną, społeczną, edukacyjną, opiekuńczą, stratyfikacyjną, legalizacyjno-kontrolną ${ }^{27}$. Można sądzić, że realizuje swoje funkcje na tyle właściwie, na ile przygotowuje dziecko do społecznego funkcjonowania we wtórnym kontekście rozwoju, a więc tam, gdzie stosunki między ludźmi nie opierają się na tak bliskiej, jak rodzinne, więzi ${ }^{28}$. Wydzielając w zadaniach tych konkretne obszary wychowania do życia publicznego, można dostrzec obszar wpływu:

- społeczno-moralnego (orientowania na wartości, kształtowania antroposfery aksjologicznej środowisk społecznych, orientacji na ład, sprawiedliwości i normatywności w życiu publicznym),

- tożsamościowego (tożsamości jednostek, ról społecznych, osobowości autonomicznej),

- poznawczego (myślenia, asymilacji wiedzy, identyfikacji, rozumienia, wyjaśniania etc.),

- rozwoju potrzeb (biologicznych, bezpieczeństwa, podporządkowania, afiliacji, akceptacji, szacunku, samorozwoju ${ }^{29}$ ).

Oddziaływanie współczesnej rodziny (jako przestrzeni kształtowanych relacji podmiotowości rodziców i dzieci) w edukacyjnym sensie przywołuje, o czym wspomniano wcześniej, kontekst także przestrzeni szkoły. Rodzina i szkoła bowiem jako podstawowe środowiska wychowawcze uzupełniają się, uczestnicząc w społecznym dyskursie o edukacji. Idąc tropem namysłu Johna Deweya, można zauważyć potrzebę rozpoznania znamion doświadczania mocy codziennej ,praktyki komunikacyjnej" rodziców i nauczycieli, ale komunikacji rozumianej jako „wymiany pomocnej w zaspokajaniu potrzeb; uwzględniającej postulaty, apele, rozkazy, wskazówki, prośby, które zaspokajają potrzebę mniejszym kosztem niż tylko osobista praca, ponieważ zapewnia współpracę innych"30. Ukierunkowanie w ten sposób uwagi rodziców i nauczycieli na znaczenie o s o b y ${ }^{31}$ staje się wy-

${ }^{27}$ Por. A. Pryba, Rodzina podstawowa instytucja i wspólnota życia społecznego?, dz. cyt., s. $17-18$.

${ }^{28}$ Por. B. Harwas-Napierała, Rodzina jako kontekst rozwojowy jednostki, w: Rozwijajacy sie czlowiek w zmieniajacym się świecie, red. J. Trempała, Bydgoszcz 1995, s. 303-304.

${ }^{29}$ Andrzej Pryba szerzej rozwija problem rozwoju potrzeb w życiu członków rodziny i korzystając z myśli Kazimierza Obuchowskiego, podkreśla wśród nich potrzeby powszechne, które dotyczą wszystkich ludzi, oraz potrzeby indywidualne charakterystyczne dla danej jednostki. Zwraca jednak szczególną uwagę na naturalny rozwój i realizację potrzeb (w tym potrzeb religijnych), jednak z dostrzeżeniem zjawisk zachwiania proporcji w określaniu naturalnego i sztucznego eksponowania potrzeb ich realizacji. Zauważone przez A. Prybę zjawiska prowadzą nie tyle do pozorności harmonijnego rozwoju człowieka, ile do fałszowania obrazu o faktycznej roli potrzeb w tym procesie. Por. A. Pryba, Rodzina podstawowa instytucja $i$ wspólnota życia społecznego?, dz. cyt., s. 8.

${ }^{30}$ H. Joas, Powstawanie wartości, Biblioteka Myśli Socjologicznej, Warszawa 2009, s. 184-185.

${ }^{31}$ H. Berner, Współczesne kierunki pedagogiczne, w: Pedagogika. Podstawy nauk o wychowaniu, red. B. Śliwerski, t. 1, Gdańsk 2006, s. 232. 
zwaniem oczekiwanej podmiotowości w kształtowanych codziennie relacjach. Ważny jest społeczny kontekst takiej refleksji skoncentrowanej na roli kluczowych osób w edukacji dziecka i relacji pomiędzy nimi oraz reprezentowaną przez nie codzienną wiedzą o wychowaniu. Takie zorientowanie prawdopodobnie spowoduje charakterystyczne dla konkretnych środowisk wychowawczych ,wyczulenia" na problem dziecięcego doświadczania: wzorów, ich adaptacji lub rekonstrukcji, wiedzy codziennej o wychowaniu, dialogowości, transmisji wartości i normatywności funkcjonowania rodziny.

Refleksja ta prowadzi jeszcze do innego zagadnienia, tj. trudności opisu dynamiki zmian zachodzących w tym obszarze refleksji o edukacji. Rodzina jako środowisko wychowania dziecka nacechowana jest taką dynamiką przemian, których znaczna część dotyczy właśnie zmian wzorów wychowania dzieci i młodzieży. Zauważona przemiana często ma jakiś związek z dostrzeganą współcześnie kontestacją wzorów i sankcjonowanych tradycją autorytetów. Niejednokrotnie wynika to z kwestionowania przez młode pokolenia znanego dotąd paradygmatycznego modelu transmisji wiedzy, charakterystycznego dla orientacji kultury utrwalającej tradycyjne autorytety oparte na tradycyjnych wartościach $^{32}$. Takie usankcjonowane tradycją wzory wychowania stają się często obiektem silnej kontestacji, a sam rodzic poddawany jest próbom odnalezienia się w przestrzeni publicznej debaty nad wychowaniem młodych pokoleń pozbawionych trwałego (w sensie stałego) punktu oparcia ${ }^{33}$. Podobne zresztą ustalenia wyprowadziła Margaret Mead, eksponując odmienność modelu ewolucji kultur postfiguratywnej i prefiguratywnej, w której wzory osobowe młodych pokoleń znacznie odbiegają od tradycyjnie postrzeganych ideałów tzw. ludzi znaczących: rodziców, nauczycieli, bohaterów literackich lub uznanych społecznie autorytetów czy innych „nieocenionych przodków”34. Zjawisko to niejednokrotnie ma związek z przywołanym powyżej kwestionowaniem paradygmatycznego modelu transmisji wiedzy i nie pozostaje bez wpływu na kształt praktyki wychowawczej współczesnych rodzin. Stawia to rodziców niejednokrotnie w trudnych sytuacjach, do których często nie zostali wcześniej przygotowani.

Z drugiej jednak strony warto podkreślić znaczenie osobowego wy s iłk u w pracy nad jakością wychowania w rodzinie i jej roli - jako naturalnego środowiska - w tym zakresie. Dotyczy to poszukiwania nowych kategorii opisu zmieniających się wzorców osobowych dzieci i kształtowania ich tożsamości w świetle zderzenia własnego światopoglądu z nowym odczytaniem

${ }^{32}$ Problem ten jest wielokrotnie eksponowany nie tylko w sferze edukacji, ale też religii, kultury (zwłaszcza kultury tzw. wysokiej), sztuki, nauk o języku czy socjologii wychowania.

${ }^{33}$ Por. Z. Konaszkiewicz, Szkice z pedagogiki muzycznej, Warszawa 2001, s. 18.

${ }^{34}$ M. Mead, Kultura i tożsamość. Studium dystansu międzypokoleniowego, tłum. J. Hołówka, Warszawa 1978, s. 58-65. 
potrzeby sensu życia ${ }^{35}$. Wzór osobowy jako społeczno-moralny model jest traktowany konkretnie jako określony typ wartości, ,zespół zalet cenionych w danym środowisku i stanowiący personifikację ideałów w procesie autokreacji lub wychowania" ${ }^{36}$. Wiąże się to $\mathrm{z}$ fazą identyfikacji dziecka z zewnętrznymi wzorami będącymi uosobieniem pożądanych cech, które warto naśladować, godne są szacunku, empatii, uczenia się społecznego, co sprawiać może, że dojrzała osobowość dorosłych już podmiotów edukacji ma odzwierciedlenie w osobowości dziecięcej ${ }^{37}$. Dawno takie uwarunkowanie zostało podjęte w środowiskach psychologów czy socjologów. Formą, jedną z wielu, oddziaływania wychowawczego dorosłych pedagogów jest zatem eksponowanie właściwych i przekonujących wzorów osobowych jako modeli motywujących do naśladowania. Pytania, jakie jednak mogą lub powinny interesować rodziców, nasuwają wątpliwości co do jednoznaczności opisów tego, w jaki sposób dzieci i dorastająca młodzież personifikuje własne ideały, wartości czy dążenia w kreacji własnego obrazu świata.

Podobnie ważne wydaje się poszukiwanie odpowiedzi na pytania o wychowanie dziecka poprzez adaptację, odtwarzanie, ale też rekonstrukcję szeroko pojętej kultury jego rodzimego środowiska. W rodzinie, w wyniku procesu inkulturacji, kształtowane mogą być już znaczenia „wzorcowe”, „idealne”, a których zewnętrzne oddziaływanie (tj. poza obszarem działania rodziny, szkoły, rodziców i nauczyciela) może być konsekwencją współczesnej ewolucji stosunku jednostki do wzorca/ideału. Warto to uwzględnić w edukacyjnej refleksji o podmiotowości w wychowaniu w rodzinie.

Pytania, jakie stawia się dziś rodzicom jako pierwszym nauczycielom dziecka, dążą do optymalizowania relacji wychowawczych właśnie w kontekście dwupodmiotowej strategii wychowania. Warto zwrócić uwagę rodziców na ich sposoby patrzenia na dziecko (co zawsze ma jakiś związek z reprezentowanymi przez nich potocznymi pedagogiami). Pytania te mogą nawiązywać do tego:

- w jaki sposób podmioty edukacji strukturalizują oraz interpretują codzienne doświadczenia relacji społecznych w rodzinie,

- jakimi posługują się interpretacjami ważnych dla siebie pojęć i zdarzeń wychowawczych,

- jakie są możliwości wydobycia z narracji dzieci ich subiektywnych definicji edukacji (pojęć: sukcesu, porażki, roli rodzica, roli dziecka, roli nauczyciela, roli rodzica, wychowania),

${ }^{35}$ B. Myrdzik, Zrozumieć siebie i świat. Szkice i studia o edukacji polonistycznej, Lublin 2006, s. 153.

${ }^{36}$ Maty stownik terminów i pojęć filozoficznych, red. A. Podsiad, Z. Więckowski, Warszawa 1983, s. 431.

${ }^{37}$ M. Chłopkiewicz, Osobowość dzieci i młodzieży, Warszawa 1980. 
- na czym może polegać i jak kształtować społeczny kontekst optymalnych interakcji zogniskowanych w rodzinie,

- w jaki sposób kształtują się relacje typu „Ja” - „Ty” w rodzinie.

\section{ZAKOŃCZENIE}

Refleksja o społecznych oddziaływaniach naturalnych środowisk wychowawczych dziecka (w tym osób, ich działań, myśli, ról społecznych, wzorów osobowych, jakie moga pełnić w edukacji) skłania do wielu przemyśleń. Otóż obok potrzeby ciagłego kształtowania charakterystycznej dla edukacji diady dwupodmiotowości ${ }^{38}$ myśli koncentrują się także wokół adekwatności opisu społecznej roli podstawowych podmiotów edukacji. Jak zauważyła Teresa Hejnicka-Bezwińska, praktyka edukacji wiąże się w ten sposób z ważnymi pytaniami o rolę osób w społecznym uczeniu się, aby ludzie chcieli i umieli budować wspólnoty społeczne zgodnie $\mathrm{z}$ podmiotowymi standardami funkcjonowania jednostki w środowisku społecznym ${ }^{39}$. W tym kontekście właśnie pożądane wysokie standardy procesów edukacji zwracają uwagę na rolę podstawowych podmiotów edukacji dziecka.

Aby zrozumieć impulsy, które od wczesnych lat rozwoju dziecka kształtuja jego stosunek do najbliższych osób, nie sposób pominąc wiedzy o samym dziecku, jego potencjale uzdolnien, profilu potrzeb, zinternalizowanych wartościach i innych dyspozycjach społecznego uczenia się. Rola takiego kapitału wiedzy dorosłych, jako bardziej doświadczonych ,interpretatorów codziennych sytuacji wychowawczych", jest w tym zakresie kluczowa. Pozwala to obu autonomicznym podmiotom zachować i wyjaśniać pajdocentryczny kontekst wspólnych działań. Można też sądzić, że w działaniach opartych na własnej inicjatywie i interpretacji własnego doświadczenia bierze udział cały człowiek, a jego codzienna aktywność społeczno-edukacyjna okazuje się autentyczna i zarazem potrzebna innym ${ }^{40}$.

${ }^{38}$ Ocena specyfiki kształtowanych relacji „dorosły-dziecko” czy „,rodzic-dziecko” niejednokrotnie zmieniała się w optyce różnych paradygmatów społecznych: od strukturalno-funkcjonalistycznych przez interpretatywistyczny do podejścia wysoce subiektywistycznego, zorientowanego na wartości, sens i osobę w humanizmie. Zawsze jednak sama relacja pomiędzy tymi podmiotami edukacji jest przedmiotem uważnej refleksji o dwupodmiotowej interakcji wychowania. Ciekawe wydają się też pytania, na ile owa relacja w ramach diady pomiędzy rodzicem (dorosłym) a wychowankiem w rodzinie dodatkowo ulega oddziaływaniom z uwagi na d y n a mikę małej grupy, jaką tworzy właśnie rodzina. Ten wątek wydaje się szczególnie interesujący.

${ }^{39}$ T. Hejnicka-Bezwińska, Pedagogika ogólna, dz. cyt., s. 228-230.

${ }^{40}$ Nawiązuję, za T. Hejnicką-Bezwińską, do potrzeby rozwijania humanistycznej wrażliwości w refleksji nad własnym doświadczaniem życia i codzienną reinterpretacją jego indywidualnego sensu. W obliczu zmieniających się dynamicznie standardów podmiotowości w wychowaniu młodych pokoleń problem tzw. nowego humanizmu staje się trudną kwestią edukacyjną. Por. tamże, s. 232-233. 


\section{SUMMARY}

The article discusses the analysis of subjectivity problems in child early education. Those matters, given from pedagogical perspective, focus on the process of child upbringing in family. The assumed relations context between natural subjects such as a parent and a child stresses the importance of interdisciplinary reflection (also sociological, pedagogical, anthropological) on the role of "community" and "self-experience" in social education practice. Those "self-experiencing" competent subjects are the child and the parent who often plays the role of the first teacher. When talking about the parent and pedagogical justification of their educational influence, we more often see the role of ,a competent teacher" to his child, the person that explains everyday events, the participant of mutual interaction they both undergo and generated by those two subjects every day. Knowledge on the process of child education and the development of his integral personality is being processed via interpretation of mutual experience and sharing attention about patterns, needs and communication in everyday world.

\section{Keywords}

upbringing, early education, subjectivity, everyday life, family, school, teacher, parent

\section{BIBLIOGRAFIA}

Ablewicz K., Teoretyczne i metodologiczne podstawy pedagogiki antropologicznej. Studium sytuacji wychowawczej, Wyd. UJ, Kraków 2003.

Berger P.L., Luckmann T., Społeczne tworzenie rzeczywistości, tłum. J. Niżnik, Wydawnictwo Naukowe PWN, Warszawa 2010.

Berner H., Współczesne kierunki pedagogiczne, w: Pedagogika. Podstawy nauk o wychowaniu, t. 1, red. B. Śliwerski, GWP, Gdańsk 2006, s. 195-295.

Chłopkiewicz M., Osobowość dzieci i młodzieży, WSiP, Warszawa 1980.

Dylag J., Kognitywne i afektywne funkcje kształcenia muzycznego $w$ ksztattowaniu podstawy twórczej dziecka w edukacji zintegrowanej, w: Twórczość codzienna w praktyce edukacyjnej, red. M. Kołodziejski, PWSZ, Płock 2009, s. 77-84.

Filipiak E., Wspólna aktywność dziecka i nauczyciela $w$ strefie rozwoju, w: Rozwijajacy się człowiek $w$ zmieniajacym się świecie, red. J. Trempała, WSP, Bydgoszcz 1995, s. 221-228.

Harwas-Napierała B., Rodzina jako kontekst rozwojowy jednostki, w: Rozwijajacy się człowiek $w$ zmieniajacym się świecie, red. J. Trempała, Wyd. WSP, Bydgoszcz 1995, s. 303-316.

Hejnicka-Bezwińska T., Pedagogika ogólna. Seria: Pedagogika wobec współczesności, Wyd. Akademickie i Profesjonalne, Warszawa 2008.

Joas H., Powstawanie wartości, Biblioteka Myśli Socjologicznej, Oficyna Naukowa, Warszawa 2009.

Kawula S., Elementy nowego paradygmatu $w$ pracy szkoty $i$ nauczyciela, w: Problemy 
etyczno-deontologiczne zawodu nauczycielskiego w okresie przemian ustrojowych w Polsce, red. A. Tchorzewski, WSP, Bydgoszcz 1993, s. 143-156.

Kołodziejski M., Music Teacher as a Researcher of Educational Process, "Musikas Zinatne Sodien: Pastavigais un Mainigais. Zinatniskorakstukrajums” 2012, v. 4, pp. 357-372 .

Konaszkiewicz Z., Nauczyciel muzyki między rutynq a twórczościq, „Kwartalnik Polskiej Sekcji ISME" nr 4, 1999, s. 40-58.

Konaszkiewicz Z., Szkice z pedagogiki muzycznej, Wyd. AMFCh, Warszawa 2001.

Leksykon PWN. Pedagogika, red. B. Milerski, B. Śliwerski, Wyd. Naukowe PWN, Warszawa 2000.

Mead M., Kultura i tożsamość. Studium dystansu międzypokoleniowego, tłum. J. Hołówka, PWN, Warszawa 1978.

Myrdzik B., Zrozumieć siebie i świat. Szkice i studia o edukacji polonistycznej, Wyd. UMCS, Lublin 2006.

Marody M., Technologie intelektu. Językowe determinanty wiedzy potocznej i ludzkiego działania, Wyd. Naukowe PWN, Warszawa 1987.

Maslow A.H., Toward a Psychology of Beign, New York 1968.

Mały słownik terminów i pojęć filozoficznych, red. A. Podsiad, Z. Więckowski, Warszawa 1983.

Pryba A., Rodzina podstawowa instytucja $i$ wspólnota życia społecznego?, „Teologia i Moralność" 11(2012), s. 7-18.

Strachanowska I. Wybrane zagadnienia uczestnictwa uczniów klas I-III w zajęciach pozalekcyjnych, w: Nauczyciel w toku pracy, Studia Pedagogiczne, red. P. Prusak, WSP, Bydgoszcz 1993, z. 26, s. 169-187.

Szczepański J., Rozważania o dniu powszednim, „Odra”3(1980), s. 30-34.

Śliwerski B., Problemy wychowania w procesie globalizacji, w: Edukacja. Kultura. Teologia. Studia ofiarowane Księdzu Profesorowi Jerzemu Bagrowiczowi z okazji 65. rocznicy urodzin, red. K. Konecki, I. Werbiński, Wyd. UMK, Toruń 2003, s. 165-180.

Trzos P., Dziecko twórca, odbiorca, krytykiem, , Życie Szkoły” 2006, nr 2(669), s. 4-8.

Trzos P.A., Dziecko w rodzinie jako środowisku społecznego „,stawania się”, „Teologia i Moralność" 1(15) 2014, s. 119-130. 